Organization-Interpol was founded to ensure and promote the widest possible mutual assistance between all criminal police authorities within the limits of the law existing in the different countries worldwide and the spirit of the Universal Declaration of Human Rights, and to establish and develop all institutions likely to contribute effectively to the prevention and suppression of ordinary law crimes.

Aims. Interpol provides a co-ordination centre (General Secretariat) for its 181 member countries. Its priority areas of activity concern criminal organizations, public safety and terrorism, drug-related crimes, financial crime and high-tech crime, trafficking in human beings and tracking fugitives from justice. Interpol centralizes records and information on international offenders; it operates a worldwide communication network.

Interpol's General Assembly is held annually. The General Assembly is the body of supreme authority in the organization. It is composed of delegates appointed by the members of the organization. Interpol's Executive Committee, which meets four times a year, supervises the execution of the decisions of the General Assembly. The Executive Committee is composed of the president of the organization, the three vice-presidents and nine delegates. Interpol's General Secretariat is the centre for co-ordinating the fight against international crime. Its activities, undertaken in response to requests from the police services and judicial authorities in its member countries, focus on crime prevention and law enforcement.

As of Jan. 2006 Interpol's Sub-Regional Bureaus were located in Abidjan, Buenos Aires, El Salvador, Harare and Nairobi. Interpol's Liaison Office for Asia is located in Bangkok.

Headquarters: 200 Quai Charles de Gaulle, 69006 Lyon,

France.

Website: http://www.interpol.int

e-mail: cp@interpol.int

President: Jackie Selebi (South Africa).

\section{Islamic Development Bank}

The Agreement establishing the IDB (Banque islamique de développement) was adopted at the Second Islamic Finance Ministers' Conference held in Jeddah, Saudi Arabia in Aug. 1974. The Bank, which is open to all member countries of the Organization of the Islamic Conference, commenced operations in 1975. Its main objective is to foster economic development and social progress of member countries and Muslim communities individually as well as jointly in accordance with the principles of the Sharia. It is active in the promotion of trade and the flow of investments among member countries, and maintains a Special Assistance Fund for member countries suffering natural calamities. The Fund is also used to finance health and educational projects aimed at improving the socioeconomic conditions of Muslim communities in non-member countries. A US $\$ 1.5 \mathrm{bn}$. IDB Infrastructure Fund was launched in 1998 to invest in projects such as power, telecommunications, transportation, energy, natural resources, petro-chemical and other infrastructure-related sectors in member countries.

Members (56 as of Jan. 2006). Afghanistan, Albania, Algeria, Azerbaijan, Bahrain, Bangladesh, Benin, Brunei, Burkina Faso, Cameroon, Chad, Comoros, Côte d'Ivoire, Djibouti, Egypt, Gabon, The Gambia, Guinea, Guinea-Bissau, Indonesia, Iran, Iraq, Jordan, Kazakhstan, Kuwait, Kyrgyzstan, Lebanon, Libya, Malaysia, Maldives, Mali, Mauritania, Morocco, Mozambique, Niger, Nigeria, Oman, Pakistan, Palestine, Qatar, Saudi Arabia,
Senegal, Sierra Leone, Somalia, Sudan, Suriname, Syria, Tajikistan, Togo, Tunisia, Turkey, Turkmenistan, Uganda, United Arab Emirates, Uzbekistan, Yemen.

Official language: Arabic. Working languages: English, French.

Headquarters: PO Box 5925, Jeddah 21432, Saudi Arabia. Website: http://www.isdb.org

President: Ahmed Mohamed Ali (Saudi Arabia).

\section{Médecins Sans Frontières (MSF)}

Origin. Médecins sans Frontières was founded in 1971 by a small group of doctors and journalists who believed that all people have a right to emergency relief.

Functions. MSF was one of the first non-governmental organizations to provide both urgently needed medical assistance and to publicly bear witness to the plight of the people it helps. Today MSF is an international medical humanitarian movement with branch offices in 18 countries. In 2003 MSF volunteer doctors, nurses, other medical professionals, logistical experts, water-and-sanitation engineers, and administrators departed on more than 3,400 missions and joined more than 16,000 locally hired staff to provide medical aid in nearly 80 countries. MSF was awarded the 1999 Nobel Peace Prize.

Headquarters: MSF International Office, Rue de Lausanne 78, CH-1211 Geneva 21, Switzerland.

Website: http://www.msf.org

Secretary-General: Marine Buissonnière.

President: Dr Rowan Gillies (Australia).

\section{North Atlantic Treaty Organization (NATO)}

Origin. On 4 April 1949 the foreign ministers of Belgium, Canada, Denmark, France, Iceland, Italy, Luxembourg, the Netherlands, Norway, Portugal, the UK and the USA signed the North Atlantic Treaty, establishing the North Atlantic Alliance. In 1952 Greece and Turkey acceded to the Treaty; in 1955 the Federal Republic of Germany; in 1982 Spain; in 1999 the Czech Republic, Hungary and Poland; and in 2004 Bulgaria, Estonia, Latvia, Lithuania, Romania, Slovakia and Slovenia, bringing the total to 26 member countries. The Alliance enables these countries to meet and cooperate in the field of security and defence.

Functions. The Alliance was established as a defensive political and military alliance of independent countries in accordance with the terms of the UN Charter. Its fundamental role is to safeguard the freedom and security of its members by political and military means. It also encourages consultation and co-operation with non-NATO countries in a wide range of security-related areas to help prevent conflicts within and beyond the frontiers of its member countries. NATO promotes democratic values and is committed to the peaceful resolution of disputes. If diplomatic efforts fail, it has the military capacity needed to undertake crisismanagement operations alone or in co-operation with other countries and international organizations.

Reform and Transformation of the Alliance. Following the demise of the Warsaw Pact in 1991, and the improved relations with Russia, NATO established close security links with the states of 